KINGA KUSZAK

ORCID 0000-0002-2430-7803

Uniwersytet im. Adama Mickiewicza

$w$ Poznaniu

\title{
JEZZYKOWY OBRAZ WOJNY WEDŁUG UCZNIÓW KLAS IV-VII SZKOŁY PODSTAWOWEJ
}

AвSTRACt. Kuszak Kinga, Językowy obraz wojny wedtug uczniów klas IV-VII szkoły podstawowej [Linguistic Image of War According to Students of Years 4-7 of Primary School]. Studia Edukacyjne nr 56, 2020, Poznań 2020, pp. 39-56. Adam Mickiewicz University Press. ISSN 1233-6688. DOI: 10.14746/ se.2020.56.3

The article discusses the linguistic image of war as an element of the linguistic worldview, based on statements made by students of years 4-7. The author follows Jerzy Bartmiński's assumption that a linguistic worldview is a linguistic interpretation of reality, which can be defined as a set of judgements about the world. These judgements may be fixed in the language itself, in its grammatical forms, lexicon, clichéd texts (e.g. proverbs), or as implied linguistic forms and texts. Language is a means of interpreting the world and the words used not so much to "render a photographic reproduction of things" as to "portray" them mentally. The author, inspired by Franciszek Hinczer's research on war conducted in 1919 among students aged 8-14, asked students of two primary schools (302 people in total) about their opinions on the same topic. The students taking part in the research, conducted a hundred years after the study was published in the Szkoła Powszechna journal, answered the following questions: What do they think a war is? What do people do during a war? What do adults do during a war and what do children do? The students' statements were analyzed and categorized. Each selected category was illustrated with sample answers from the respondents. The presentation of the results was preceded by an analysis of the notion and image of war in selected dictionaries of the Polish language.

Key words: linguistic worldview, the notion of war, linguistic image of war, linguistic image of war in statements of year 4-7 students, language competencies of students in upper years of primary school

\section{Wprowadzenie}

W 1920 roku nauczyciel szkoły we Włocławku opublikował na łamach „Szkoły Powszechnej”1 artykuł, zatytułowany „Stosunek dziecka polskiego

${ }^{1}$ F. Hinczer, Stosunek dziecka polskiego do wojny, „Szkoła Powszechna”, zeszyt II, Warszawa 1920, s. 63-79. 
do wojny". Przedstawił w nim rezultaty zadania, jakie zaproponował swoim uczniom:

dnia 30 stycznia 1918 roku napisałem na tablicy w swej klasie następujące zdanie: „Czy chciałbyś, żeby wojna się skończyła i dlaczego" (...). Napiszcie to wszystko, co teraz wam przyjdzie. Piszcie szczerą prawdę"2.

W lutym i marcu 1918 roku, dzięki życzliwości innych nauczycieli, zebrał 504 wypowiedzi dzieci 8-14-letnich na temat wojny, które przedstawił w artykule. Wśród nich znalazły się narracje prezentujące własne doświadczenia, indywidualną perspektywę, marzenia o zakończeniu niewoli. Zainspirowana wynikami tych badań, postanowiłam zbadać, jaki jest językowy obraz wojny współczesnych dzieci. Poprosiłam 302 uczniów klas IV-VII ${ }^{3}$ z dwóch szkół podstawowych zlokalizowanych w Poznaniu o wypowiedzi na temat: „Czym według Ciebie jest wojna? Co robią ludzie w trakcie wojny? Co podczas działań wojennych robią dorośli, a co robią dzieci?" Zależało mi, aby poznać rozważania tych uczniów na temat indywidualnego obrazu wojny, refleksji i przemyśleń związanych z czasem wojennego niepokoju, a więc to, co ujmujemy obecnie jako elementy językowego obrazu świata.

\section{Pojęcie: językowy obraz wojny}

Językowy obraz świata ujmuję za Jerzym Bartmińskim jako

zawartą $\mathrm{w}$ języku interpretację rzeczywistości, którą można ująć w postaci zespołu sądów o świecie. Mogą to być sądy bądź to utrwalone w samym języku, w jego formach gramatycznych, słownictwie, kliszowanych tekstach (np. przysłów), bądź to przez formy i teksty języka implikowane ${ }^{4}$.

Za pomocą języka człowiek może interpretować świat, a słowa którymi się posługuje nie tyle „odwzorowują rzeczy fotograficznie”, lecz „portretują je mentalnie" ${ }^{\prime \prime}$. W procesie interpretowania świata każda jednostka jest „podmiotem doświadczającym" ${ }^{\prime}$, jest aktywna, przyjmuje indywidualną perspektywę, dokonuje takiej a nie innej konceptualizacji rzeczywistości, którą „,ogląda”. Interpretacja świata nie może bowiem być zunifikowana; zakłada wiele możliwych spojrzeń7, wiele punktów widzenia, zaś przyjęty przez podmiot punkt

2 Tamże, s. 63.

${ }^{3}$ W badaniu wzięło udział 149 dziewczynek, 148 chłopców, zaś 5 osób nie podało imienia ani nie określiło płci.

${ }^{4}$ J. Bartmiński, Językowe podstawy obrazu świata, Lublin 2012, s. 76-76.

5 Tamże, s. 77.

${ }^{6}$ Tamże, s. 208.

${ }^{7}$ R. Tokarski, Światy za słowami. Wykłady z semantyki leksykalnej, Lublin 2014, s. 65. 
widzenia funkcjonuje „jako zespół dyrektyw kształtujących treść i strukturę treści słów i całych wypowiedzi” ${ }^{8}$. Jerzy Bartmiński dodaje, że przyjęta perspektywa „różnicuje znaczenia słowa przez to, że bezpośrednio determinuje wybór podstawy definicji, a pośrednio - dobór kategorii i sposób ich wypełnienia" ${ }^{\prime \prime}$. Perspektywa językowego ujmowania świata jest zatem subiektywna, a

zarówno codzienne doświadczenie, jak i najgłębsza refleksja wskazują na tę ułomność języka, upatrując w owej dziedzinie odległą krainę, do której tylko język prowadzi, a i on nigdy całkiem do niej nie dociera ${ }^{10}$.

„Ułomność" perspektywy, na którą wskazuje Wilhelm von Humboldt wyraża się właśnie w tym, że jest indywidualna. Zatem, z tego względu „nie do dociera” do istoty rzeczy, lecz odzwierciedla indywidualne myślenie, rozumienie, interpretowanie jakiegoś faktu w rzeczywistości. Jak dodaje Tomasz Nowak, językowy obraz świata

wydobywa się z metafor pojęciowych, a także stereotypów językowych i konotacji. Stereotypy językowe tkwią w utrwalonych w języku zbitkach słownych, w przysłowiach, frazeologizmach i kolokacjach. (...) Konotacje to z kolei zabarwienia wyrazów, $\mathrm{w}$ tym kryjące się $\mathrm{w}$ nich wartości ${ }^{11}$.

Podążając tą drogą, językowy obraz wojny będę postrzegała jako subiektywny, wynikający z wiedzy uczniów, ich refleksji, wrażliwości, konceptualizację wyrażoną ich słowami, obraz wojny. Ten obraz, co postaram się pokazać, nie jest oceną wartościowania, zakorzenionych w języku metafor i stereotypów.

\section{Językowe ujęcie wojny według uczniów klas IV-VII ${ }^{12}$}

W Popularnym stowniku języka polskiego ${ }^{13}$ pojęcie wojny zdefiniowano w dwóch znaczeniach, jako:

1) konflikt zbrojny; zorganizowana walka zbrojna między państwami, narodami lub grupami społecznymi, religijnymi itp., prowadzona dla osiągnięcia zamierzonych celów;

2) awantury, kłótnie, spory, bójki.

${ }^{8}$ J. Bartmiński, Językowe podstawy obrazu świata, s. 78.

9 Tamże, s. 82.

${ }^{10}$ W. Humboldt, O myśli i mowie, Warszawa 2002, s. 274.

11 T. Nowak, Język w świetle odkryć nauki, Kraków 2011, s. 47.

12 Wątek ten rozwinęłam w artykule K. Kuszak Interpretacje pojęcia wojny wedtug uczniów klas starszych szkoły podstawowej, [w:] Dziecięce interpretacje rzeczywistości. Werbalne i pozawerbalne reprezentacje dziecięcych znaczeń, red. E. Kochanowska (w przygotowaniu).

${ }^{13}$ Popularny stownik jezzyka polskiego, Poznań 2009, s. 562. 
Z kolei Słownik języka polskiego PWN pojęcie to ujmuje jako:

1) zorganizowaną walkę zbrojną między państwami, narodami lub grupami społecznymi, religijnymi itp., prowadzoną dla osiągnięcia zamierzonych celów, np. zagarnięcia obcego terytorium;

2) kłótnię, bójkę;

3) grę karcianą polegającą na automatycznym zbieraniu lew ${ }^{14}$.

W Internetowym słowniku języka polskiego wymieniono kilka typów wojen, jak na przykład: atomowa (jądrowa, nuklearna), biologiczna, błyskawiczna, domowa, podjazdowa, pozycyjna, prewencyjna, psychologiczna, secesyjna, święta, totalna. Słownik języka polskiego z frazeologizmami i przysłowiami ${ }^{15} \mathrm{uzu}-$ pełnia tę listę o wojnę: obronną, zaczepną, bratobójczą, bakteriologiczną, zimną, zaś Słownik frazeologiczny - o wojnę nerwów i wojnę na górze ${ }^{16}$. Władysław Kopaliński ${ }^{17}$ dodaje jeszcze inne typy, w tym: brudną wojnę, dziwną wojnę, wojnę kokoszą, wojnę peloponeską, wojnę trojańską, trzydziestoletnią, wojny krzyżowe, sukcesyjne. We wspomnianym słowniku internetowym za synonimy tego pojęcia uznano: kampanię, wojenkę, walkę ${ }^{18}$. Natomiast, w Słowniku $3 w 1$ wyrazów obcych, synonimów, frazeologicznym Wydawnictwa Buchmann ${ }^{19}$ zawarto synonimy odnoszące się do dwóch znaczeń pojęcia wojna:

1) konflikt zbrojny, walka;

2) spór, kłótnia, konflikt.

Z kolei, w Słowniku idiomów polskich ${ }^{20}$ pojęciu wojna przyporządkowano następujące idiomy: być w lesie; pójść do lasu; chłopcy z lasu; coś spłynęło krwią; iść na barykady, kłaść, położyć nieprzyjaciela, wroga pokotem, trupem; mięso armatnie; przelew (rozlew) krwi; święta wojna; taktyka spalonej ziemi; tonąć we krwi; wydać bitwę (wojnę); wyjść z lasu; czyn zbrojny; paść, polec, zginąć na polu chwały.

A zatem, już ta pobieżna analiza ujęć słownikowych wspomnianego pojęcia wskazuje na wielość ujęć i różnorodność perspektyw. Jerzy Bartmiński odnosząc się do definicji słownikowych, zaznacza, że ich treść odpowiada wiedzy naukowej (podanej językiem specjalistycznym), nie zaś wiedzy „zdroworozsądkowej"21. Dodaje, że wiedza naukowa jest pod pewnymi względami bogatsza od potocznej, a pod innymi uboższa. U jej źródeł znajduje się

${ }^{14}$ L. Drabik i in., Stownik języka polskiego PWN, Warszawa 2011, s. 1160.

15 E. Dereń, T. Nowak, E. Polański, Stownik jezzyka polskiego z frazeologizmami i przystowiami, Warszawa 2012, s. 470.

${ }^{16}$ E. Sobol, Stownik frazeologiczny z Bralczykiem, Warszawa 2008, s. 367-368.

17 W. Kopaliński, Stownik mitów i tradycji kultury, Warszawa 2011, s. 1445-1447.

${ }^{18}$ https://sjp.pwn.pl/szukaj/wojna.html, [dostęp: 15.04.2020].

19 Stownik 3w1 wyrazów obcych, synonimów, frazeologiczny, Warszawa 2012, s. 545.

${ }^{20}$ L. Drabik, E. Sobol, A. Stankiewicz, Stownik idiomów polskich PWN, Warszawa 2006, s. $189-190$.

${ }^{21}$ J. Bartmiński, Językowe podstawy obrazu świata, s. 35. 
postawa wobec rzeczywistości, którą charakteryzuje zwężenie punktu widzenia, nastawienie wyłącznie na cele poznawcze oraz ujęcie wyników tego poznania w system pojęciowy (...). W przeciwieństwie do niej wiedza potoczna, która leży u podstaw języka ogólnego (można ją nazwać wiedzą „językową"), odznacza się tym, że ujmuje rzeczywistość w wielu aspektach, preferuje pragmatyczne, a nie teoretyczne podejście, a spetryfikowanych charakterystyk przedmiotów nie zamyka w spójny system ${ }^{22}$.

I tak właśnie jest w przypadku uczniowskich interpretacji pojęcia „wojny". Uczniowie w swoich wypowiedziach rozszerzają i uzupełniają "tradycyjną" definicję słownikową, akcentując elementy, które z ich perspektywy są istotne i według nich są/mogą być użyteczne. Z wypowiedzi uczniów wynika, że wojna to: 1) działanie prowadzące do utraty życia $(36,09 \%)^{23}$; 2) konflikt (kłótnia, spór, sprzeczka, waśń) (27,15\%); 3) walka (bitwa, bójka) (17,22\%); 4) „trudne emocje”" cierpienie, rozpacz, smutek, żal itp. $(30,46 \%)$; 5) niszczenie (zniszczenia) $(8,6 \%) ; 6)$ codzienne doświadczenie $(5,29 \%)$. Zatem, obraz wojny stworzony przez uczniów jest bogatszy, aniżeli definicja zawarta w Popularnym słowniku języka polskiego ${ }^{24}$. W tabeli 1 zamieszczono podkategorie do każdej z tych kategorii wyłonionych na podstawie analizy wypowiedzi uczniów, uzupełnione wybranymi przykładami.

Tabela 1

Kategorie pojęcia wojny według uczniów klas IV-VII

\begin{tabular}{|c|c|c|}
\hline Kategoria & Podkategorie & Wybrane wypowiedzi uczniów \\
\hline \multirow[t]{4}{*}{$\begin{array}{l}\text { Działanie } \\
\text { prowa- } \\
\text { dzące do } \\
\text { utraty } \\
\text { życia }\end{array}$} & $\begin{array}{l}\text { wzajemne } \\
\text { zabijanie }\end{array}$ & $\begin{array}{l}\text { "wojna to jest straszny czas, kiedy ludzie z innego kraju zabijaja } \\
\text { inne osoby codziennie" (ch., kl. IV), "wojna jest czymś strasz- } \\
\text { nym, na wojnie gina ludzie (...)" (ch., kl. V), "wedtug mnie } \\
\text { wojna, to okres, gdy dzieja się potworne rzeczy. Ludzie siebie } \\
\text { morduja" (dz., kl. V), "Chaos na świecie, zabijanie siebie nawza- } \\
\text { jem" (dz., kl. VI), "wojna, wedtug mnie, to pole walki, na którym } \\
\text { ludzie się zabijaja" (dz., kl. VI) }\end{array}$ \\
\hline & $\begin{array}{l}\text { strata } \\
\text { bliskich ludzi }\end{array}$ & $\begin{array}{l}\text { „wedtug mnie wojna to utrata bliskich (...), to smutek i złość } \\
\text { (...). Wojnie towarzyszy śmierć i samotność" (dz., kl. VI), „we- } \\
\text { dług mnie to jest okres śmierci, zagłady i smutku. Ludzie traca } \\
\text { najblizssze im osoby” (dz., kl. VI) }\end{array}$ \\
\hline & $\begin{array}{l}\text { masowe } \\
\text { mordowanie }\end{array}$ & $\begin{array}{l}\text { "stowo wojna, wedtug mnie, kojarzy się z krwia i płaczem, bo } \\
\text { bardzo dużo ludzi zabija i umierajá, i wiele rodzin na tym traci” } \\
\text { (ch., kl. VI), "wojna to (...) sposób na wymordowanie milionów, } \\
\text { a nawet miliardów ludzi” (dz., kl. VI), "wojna to problem, zagła- } \\
\text { da ludzi" (dz., kl. VII) }\end{array}$ \\
\hline & $\begin{array}{l}\text { pozbawianie } \\
\text { życia niewin- } \\
\text { nych ludzi }\end{array}$ & $\begin{array}{l}\text { "wojna to zabijanie niewinnych ludzi" (dz., kl. VII), "wojna to } \\
\text { zabicie ludzi młodych i starych" (ch., kl. VI), "wielu niewinnych } \\
\text { ginie w trakcie takich wydarzeñ" (ch., kl. VII) }\end{array}$ \\
\hline
\end{tabular}

22 Tamże.

${ }^{23}$ Dane nie sumują się do $100 \%$, ponieważ każdy uczeń mógł w zaproponowanej definicji zawrzeć kilka elementów odpowiadających różnym kategoriom.

24 Popularny słownik języka polskiego, Poznań 2009, s. 562. 


\begin{tabular}{|c|c|c|}
\hline \multirow[t]{3}{*}{ Konflikt } & $\begin{array}{l}\text { między ludź- } \\
\text { mi }\end{array}$ & $\begin{array}{l}\text { "to kłótnia pomiędzy osobami, które nie umieja się pogodzić" } \\
\text { (dz., kl. V), "kiedy dwoje ludzi pokłóci się nawet o drobna rzecz" } \\
\text { (dz., kl. VI), "jest konfliktem między (najczéściej) osobami, które } \\
\text { zamiast używać stosownych argumentów, by postawić na swoim, } \\
\text { wola użyć przemocy. Cierpi na tym społeczeństwo" (?, kl. V), }\end{array}$ \\
\hline & $\begin{array}{l}\text { między pań- } \\
\text { stwami }\end{array}$ & $\begin{array}{l}\text { "dla mnie wojna to konflikt między kilkoma państwami” (dz., kl. } \\
\mathrm{VI}), \text {,wojna, to sprzeczka pomiędzy krajami” (ch., kl. VI), "woj- } \\
\text { na to konflikt między państwami lub miastami" (dz., kl. V), } \\
\text { "wojna to nieporozumienie pomiędzy dwoma np. państwami, } \\
\text { które doprowadza do starcia militarnego" (ch., kl. V), "wojna to } \\
\text { kłótnia pomiędzy dwoma, trzema krajami" (dz., kl. V), }\end{array}$ \\
\hline & $\begin{array}{l}\text { konflikt } \\
\text { zbrojny }\end{array}$ & $\begin{array}{l}\text { "wojna to konflikt zbrojny. Podczas niej wiele istot żywych cierpi } \\
\text { i w zasadzie ma silne nacechowanie negatywne" (dz., kl. VI), } \\
\text { "konfliktem zbrojnym między dwoma lub więcej stronami" } \\
(?, \mathrm{kl} \text {. VI), }\end{array}$ \\
\hline \multirow[t]{5}{*}{ Walka } & $\begin{array}{l}\text { między ludź- } \\
\text { mi }\end{array}$ & $\begin{array}{l}\text { "wojna to bitwa z rodzeństwem" (dz., kl. VI), "wojna jest bitwa } \\
\text { między ludzmi" (dz., kl. VII), "wedtug mnie jest to krwawa } \\
\text { walka dwóch lub więcej drużyn" (ch., kl. VI), }\end{array}$ \\
\hline & $\begin{array}{l}\text { między pań- } \\
\text { stwami }\end{array}$ & $\begin{array}{l}\text { "wojna: bitwa między jednym krajem a drugim" (dz., kl. VI), } \\
\text { "jest to bitwa pomiędzy dwoma krajami" (ch., kl. VI), "wojna } \\
\text { to jest taki okres, w którym jest ileś wrogich królestw, które się } \\
\text { "bijg" (wtączając w to strzelanie z pistoletu)" (dz., kl. VII) }\end{array}$ \\
\hline & $\begin{array}{l}\text { z jakiegoś } \\
\text { powodu }\end{array}$ & $\begin{array}{l}\text { "wojna to walka o dany teren" (dz., kl. VI), "stanem bitwy (...) } \\
\text { często na tle politycznym lub religijnym" (dz., kl. VI), "między } \\
\text { dwoma walczacymi o terytorium państwami" (dz., kl. VII), } \\
\text { "wojna to walka o władzę i udziały" (ch., kl. VII), "wedtug mnie, } \\
\text { wojna to bitwa o coś, co jest dla kogoś ważne" (dz., kl. V) }\end{array}$ \\
\hline & $\begin{array}{l}\text { z wyko- } \\
\text { rzystaniem } \\
\text { narzędzi } \\
\text { (środków) } \\
\text { przemocy }\end{array}$ & $\begin{array}{l}\text { "to walka zbrojna" (ch., kl. VII), "moim zdaniem, wojna to } \\
\text { inaczej walka, w której używa się broni" (dz., kl. V), "(...) ileś } \\
\text { wrogich królestw, które się "bija" (wtaczając w to strzelanie z pi- } \\
\text { stoletu)" (dz., kl. VII) }\end{array}$ \\
\hline & $\begin{array}{l}\text { prowadząca } \\
\text { do przelewu } \\
\text { krwi i śmierci }\end{array}$ & $\begin{array}{l}\text { "walka, w której się ginie" (ch., kl. VI), „zabijesz komuś brata, } \\
\text { ale twój też może nie wrócić" (ch., kl. VI), "na wojnie gina lu- } \\
\text { dzie" (ch., kl. V) }\end{array}$ \\
\hline \multirow[t]{4}{*}{$\begin{array}{l}\text { "Trudne" } \\
\text { emocje }\end{array}$} & $\begin{array}{l}\text { cierpienie } \\
\text { (rozpacz) }\end{array}$ & $\begin{array}{l}\text { "wyrządza dużo szkód i cierpienia" (dz., kl. VI), „według mnie, } \\
\text { wojna to obraz zniszczenia, śmierci i cierpienia" (ch., kl. VII), } \\
\text { "moim zdaniem, wojna to śmierć, rozpacz" (?, kl. V) }\end{array}$ \\
\hline & smutek & $\begin{array}{l}\text { "wojna to (...) bardzo dużo smutku” (dz., kl. VI), "wojna to jest } \\
\text { wielki hatas i smutek" (dz., kl. VI) }\end{array}$ \\
\hline & $\begin{array}{l}\text { strach } \\
\text { (trwoga) }\end{array}$ & $\begin{array}{l}\text { "(...) ciagty strach, walka o przetrwanie" (dz., kl. VII), "wojna to } \\
\text { wydarzenie, kiedy ludzie żyja w strachu, niepokoju” (dz., kl. VI), } \\
\text { "czas głodu i trwogi" (dz., kl. V) }\end{array}$ \\
\hline & samotność & „wojnie towarzyszy śmierć i samotność" (dz., kl. VI) \\
\hline
\end{tabular}




\begin{tabular}{|c|c|c|}
\hline $\begin{array}{l}\text { "Trudne" } \\
\text { emocje }\end{array}$ & $\begin{array}{l}\text { złość (gniew, } \\
\text { nienawiść) }\end{array}$ & $\begin{array}{l}\text { "moim zdaniem, wojna to nienawiść do siebie" (dz., kl. V), } \\
\text { "wojna to zło, nienawiść (...)" (dz., kl. V), "krew, śmierć, bum } \\
\text { bum, (...), gniew" (ch., kl. V), "wojna kojarzy mi się ze złością" } \\
\text { (ch., kl. V) }\end{array}$ \\
\hline \multirow[t]{2}{*}{$\begin{array}{l}\text { Niszcze- } \\
\text { nie }\end{array}$} & $\begin{array}{l}\text { dóbr mate- } \\
\text { rialnych } \\
\text { (zabytków) }\end{array}$ & $\begin{array}{l}\text { "wiele miast zostaje zniszczonych" (ch., kl. VI), "zniszczona } \\
\text { zostaje przyroda”, ", dochodzi do zniszczenia miast i przyrody" } \\
\text { (ch., kl. VII), ",(..) i niszczonych jest wiele pięknych miejsc } \\
\text { związanych nie tylko z natura, ale i z historia naszych przod- } \\
\text { ków” (dz., kl. VII), "cenne pamiątki i zabytki sa niszczone” } \\
\text { (ch., kl. VII) }\end{array}$ \\
\hline & przyrody & $\begin{array}{l}\text { "(...)gina też zwierzęta" (dz., kl. VII), "ginie dużo osób oraz } \\
\text { konie" (dz., kl. VI) }\end{array}$ \\
\hline \multirow{4}{*}{$\begin{array}{l}\text { Codzien- } \\
\text { ne } \\
\text { doświad- } \\
\text { czenie }\end{array}$} & $\begin{array}{l}\text { kłótnie (nie- } \\
\text { porozumie- } \\
\text { nia) }\end{array}$ & $\begin{array}{l}\text { "wojna to jest wtedy, gdy Zuza M. o mnie coś powie, to jest ok, } \\
\text { ale gdy ja to zrobie, to wojna na cała szkotę. Wojna to moje relacje } \\
\text { z Zuzq" (dz., kl. VI) }\end{array}$ \\
\hline & rywalizacja & „wojna to sa emocje w szatni po lekcji WF" (dz., kl. VI) \\
\hline & $\begin{array}{l}\text { temat filmów } \\
\text { i gier kompu- } \\
\text { terowych }\end{array}$ & $\begin{array}{l}\text { "wojna jest głównym tematem gier komputerowych (...) tematem } \\
\text { filmów" (ch., kl. V), „Star Wars" (ch., kl. VI) }\end{array}$ \\
\hline & koronawirus & „koronawirus (...) rozwalony świat” 25 (ch., kl. V) \\
\hline
\end{tabular}

Źródło: badania własne.

W interpretacjach zaproponowanych przez uczniów zaznacza się ich negatywne nastawienie do wszystkiego, co wiąże się z udziałem w konfliktach, nieporozumieniach, przemocy, wojnie. Badani podkreślają bezsensowność i okrucieństwo działań wojennych, na przykład: „(...) uważam, że jest to okropna rzecz i nigdy nie chce jej przeżyć" (dz., kl. VII), "wojna jest dla mnie (...) po prostu straszna rzecz” (ch., kl. VII), "(...) nie chce, żeby w Polsce kiedykolwiek byty wojny” (dz., kl. V), "wojna to jest zło, którego nikt nie chce, ludzie umieraja i nie maja szansy mieć chwili wytchnienia, bo caty czas musisz uważać" (ch., kl. VI), "wojna to okropny czas, w którym gina ludzie i cierpią" (dz., kl. V), "dla mnie wojna to najokropniejsza rzecz na świecie. Ludzie umieraja, traca rodziny, chowaja się" (dz., kl. V), "wojna jest okropna. Umiera wtedy wiele ludzi” (dz., kl. V), "nic pożytecznego z niej przeważnie nie wynika" (dz., kl. V).

\section{Językowy obraz aktywności ludzi w trakcie wojny według uczniów}

Poproszono uczniów, aby określili, jakiego rodzaju aktywność podejmują ludzie podczas wojny. Sformułowali oni 820 propozycji tej aktywności ${ }^{26}$,

${ }^{25}$ Badania prowadzono przed ogłoszeniem stanu epidemicznego w Polsce, kiedy do naszego kraju docierały pierwsze medialne informacje z Chin.

${ }^{26}$ Niektórzy uczniowie wymieniali i opisywali kilka aktywności. 
które zostały pokategoryzowane, a wyłonione kategorie zaprezentowano w tabeli 2 wraz z przykładowymi wypowiedziami uczniów.

Tabela 2

Aktywności ludzi podczas trwania wojny według uczniów klas IV-VII

\begin{tabular}{|c|c|c|}
\hline $\begin{array}{c}\text { Kategorie } \\
\text { aktywności } \\
\text { ludzi }\end{array}$ & $\%$ & Przykłady wypowiedzi uczniów \\
\hline $\begin{array}{l}\text { Związane } \\
\text { z walką (za- } \\
\text { bijaniem) }\end{array}$ & 34,63 & 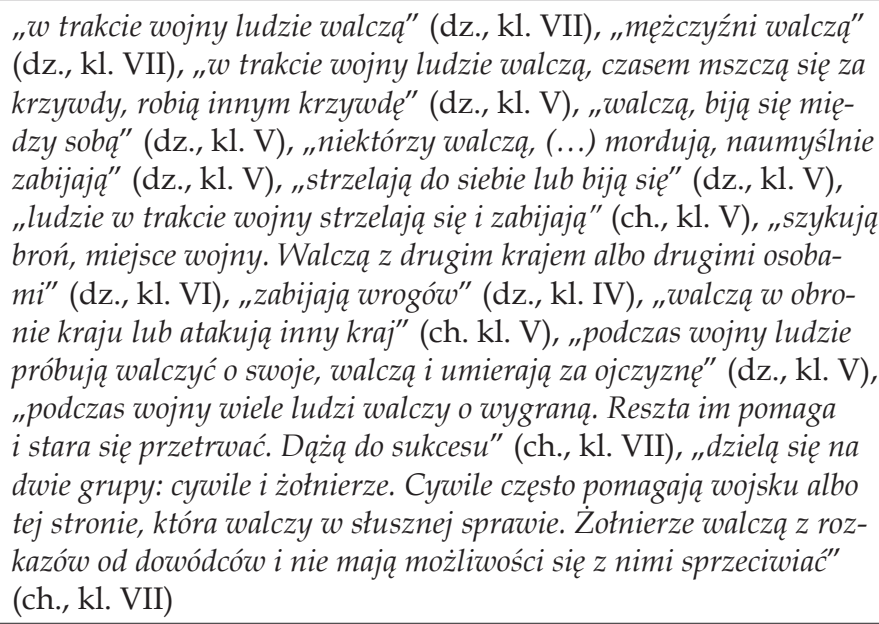 \\
\hline $\begin{array}{l}\text { Związane } \\
\text { z ochroną } \\
\text { (obroną, } \\
\text { przeżyciem, } \\
\text { przetrwa- } \\
\text { niem) }\end{array}$ & 20,97 & $\begin{array}{l}\text { "w trakcie wojny ludzie (...) chronią siebie i rodzine, wspieraja sie- } \\
\text { bie, staraja się przetrwać ten trudny czas" (ch., k. VII), "w trakcie } \\
\text { wojny ludzie próbują przetrwać i nie odnieść znaczacych strat" } \\
\text { (ch., kl. VII), "ludzie podczas wojny (...) chowaja się, próbują prze- } \\
\text { trwać" (dz., kl. VII), ",bronia siebie, rodzine, znajomych, przedmio- } \\
\text { ty" (ch., kl. VII), "ludzie w trakcie wojny próbuja się chronić, ale } \\
\text { gdy się to nie uda, to dzieje się przykra rzecz" (dz., kl. V), "chowaja } \\
\text { się w schronach" (ch., kl. VI), "moim zdaniem, ludzie w trakcie } \\
\text { wojny uciekaja do kanatów lub piwnic, po prostu w bezpieczne miej- } \\
\text { sce" (ch., kl. V) }\end{array}$ \\
\hline $\begin{array}{l}\text { Związane } \\
\text { z ucieczką } \\
\text { (emigracją) }\end{array}$ & 14,02 & $\begin{array}{l}\text { "uciekaja jak najdalej od miejsca walki, np. do państwa, w którym } \\
\text { jej nie ma” (ch., kl. V), "w trakcie wojny ludzie emigruja do innych } \\
\text { krajów" (ch., kl. V), "uciekaja do innych krajów, w których nie ma } \\
\text { wojny" (dz., kl. V), „przeprowadzają się do innych krai, w których } \\
\text { jest bezpiecznie" (dz., kl. V), „uciekają do Europy” (ch., kl. VI) }\end{array}$ \\
\hline $\begin{array}{l}\text { Związane } \\
\text { z cierpie- } \\
\text { niem }\end{array}$ & 11,11 & $\begin{array}{l}\text { "ptacza po umartych, modla się do Boga o szczęście” (dz., kl. V), } \\
\text { "ptacza, czują smutek, strach" (ch., kl. V), "mamy broniq swoje } \\
\text { dzieci. Martwia się o siebie i swoich bliskich. Dzieci boja się o swo- } \\
\text { ich ojców" (ch., kl V), "boja się o życie swoje i bliskich" (?, kl. VI), } \\
\text { "cierpia, sa nieszczęśliwi" (ch., kl. V), "tęsknią za bliskimi” } \\
\text { (dz., kl. VII), ",cywile żyją w strachu, nie wiedza czy przeżyją do } \\
\text { jutra, nie wiedza, czy będa mieli co jeść, lub pić" (dz., kl. VII) }\end{array}$ \\
\hline
\end{tabular}




\begin{tabular}{|c|c|c|}
\hline $\begin{array}{l}\text { Związane } \\
\text { z utratą } \\
\text { życia }\end{array}$ & 7,68 & 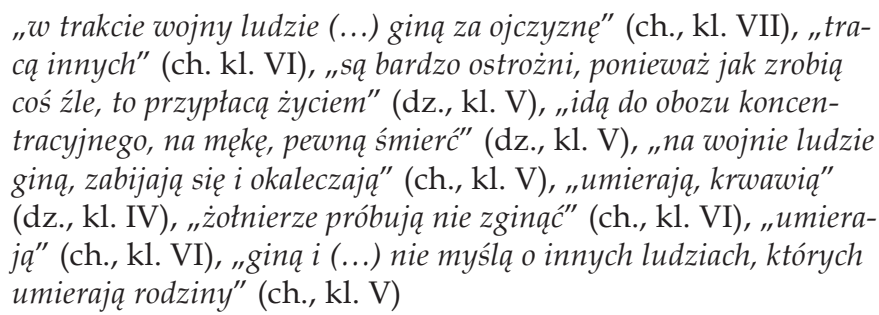 \\
\hline $\begin{array}{l}\text { Związane } \\
\text { z życiem }\end{array}$ & 10,00 & 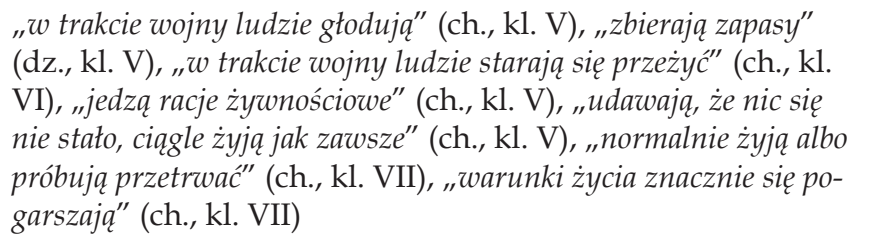 \\
\hline Inne & 0,97 & $\begin{array}{l}\text { „sa wierni ojczyźnie” (ch., kl. V), "maja niskie poczucie własnej } \\
\text { wartości” (dz., kl. VI), „oszukuja” (dz., kl. VI), "starają się złago- } \\
\text { dzić nieporozumienia” (dz., kl. VII) }\end{array}$ \\
\hline
\end{tabular}

Źródło: badania własne.

$\mathrm{Z}$ danych przedstawionych $\mathrm{w}$ tabeli wynika, że wojna kojarzy się uczniom z bezpośrednią walką (zabijaniem, biciem się z wykorzystaniem różnych narzędzi służących do walki i zabijania "bronią palną, ostrą amunicja, zabijaja się" (ch., kl. VII)), której nie można zaniechać. Wojna jest związana $\mathrm{z}$ walką, niezależnie od woli jednostek (patrz ostatnia wypowiedź w tabeli odnosząca się do kategorii walka). Ludzie są wobec niej bezradni, wkręceni w machinę wojennych działań, stają się narzędziami w walce: „są zaciagnięci do wojska" (ch., kl. VII).

Stosunkowo niewielu, bo jedynie 10,00\%, uczniów dostrzega, że w trakcie wojny ludzie wykonują szereg czynności związanych z życiem i próbują $\mathrm{w}$ tych trudnych, nienaturalnych warunkach organizować życie własne i bliskich. Znaczna część uczniów zwraca uwagę na działania związane z ochroną siebie, rodziny, dzieci. Jednak ta ochrona $w$ wyobrażeniach badanych wiąże się $\mathrm{w}$ dużym stopniu z przebywaniem, chronieniem się $\mathrm{w}$ bunkrach i piwnicach. W wypowiedziach uczniów dominuje zatem obraz aktywności ludzi $\mathrm{w}$ trakcie wojny znany im z filmów historycznych, zwłaszcza odnoszących się do II wojny światowej. To obraz romantycznego bohatera umierającego za kraj z tradycyjnym stereotypowym podziałem ról i zadań: „mężczyźni walcza w polu bitwy, nawet czasami dzieci, natomiast kobiety (jeśli dziecko jest w domu) starają się opiekować dzieckiem” (dz., kl. V), "mężczyźni wstępuja do wojska oraz zostawiaja własne rodziny. Kobiety i dzieci pewnie musza się ukrywać, albo uciekać z kraju” (dz. kl. VII), "mężczyźni ida walczyć, kobiety pomagaja w szpitalach polowych" (dz., kl. VII). Uczniowie dostrzegają też zmienione warunki życia, 
w których ludzie próbują „,normalnie żyć” i „każdy żyje jak może” (ch., kl. VI) ale też, jak to zauważyła jedna z dziewczynek: „doceniaja nawet najmniejsza rzecz, czy pomoc, dużo bardziej niż my dziś" (dz., kl. VI).

\section{Obraz aktywności dorosłych w trakcie wojny według uczniów}

W odniesieniu do aktywności dorosłych w trakcie wojny, uczniowie sformułowali 548 skojarzeń, które poddano analizie i pokategoryzowano. Tabela 3 przedstawia wyodrębnione kategorie i przykładowe odpowiedzi uczniów. Najwięcej wypowiedzi $(21,90 \%)$ dotyczyło trudu wojennego życia, niełatwej codzienności wypełnionej staraniami, zapewnieniem pożywienia i tym podobnymi. Uczniowie dokonali oceny jakości życia dorosłych podczas wojennego niepokoju, wskazując na trudności, obciążenia (także emocjonalne), zmaganie się z biedą, niedostatkiem, strachem. Ich wypowiedzi odnosiły się też do zadań, jakie podejmują dorośli w związku z ich odpowiedzialnością za najmłodsze pokolenie. Aż 18,43\% skojarzeń zorientowanych było wokół zagadnienia ochrony (obrony, troski) dzieci. Badani postrzegają też wojnę jako walkę (15,33\% odpowiedzi). Stosunkowo niewielu uczniów $(5,30 \%)$ odnosiło się do śmierci jako doświadczenia będącego udziałem ludzi w sytuacji wojny.

Tabela 3

Aktywności dorosłych podczas wojny w opiniach uczniów klas IV-VII

\begin{tabular}{|c|c|c|}
\hline $\begin{array}{l}\text { Kategorie } \\
\text { aktywności } \\
\text { dorosłych }\end{array}$ & $\%$ & Przykłady wypowiedzi uczniów \\
\hline $\begin{array}{l}\text { Codzienne } \\
\text { życie }\end{array}$ & 21,90 & 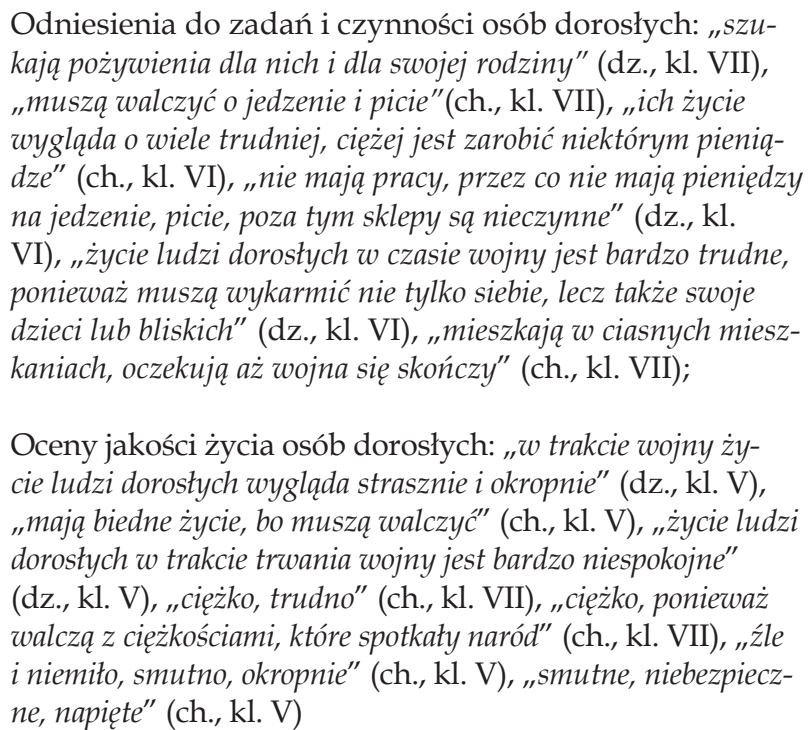 \\
\hline
\end{tabular}




\begin{tabular}{|c|c|c|}
\hline $\begin{array}{l}\text { Ochrona } \\
\text { dzieci }\end{array}$ & 18,43 & 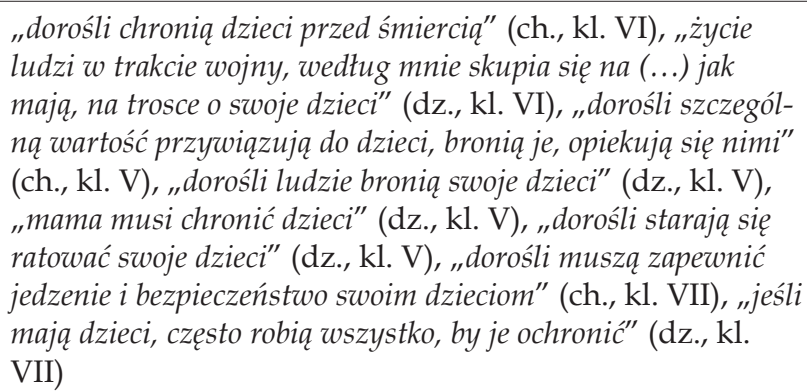 \\
\hline Walka & 15,33 & 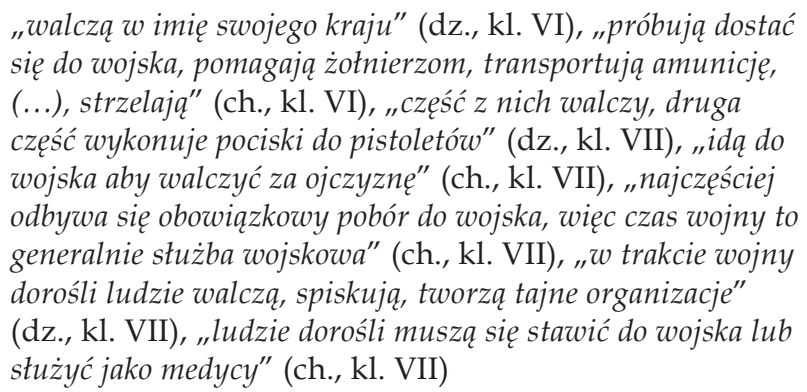 \\
\hline Emocje & 13,50 & 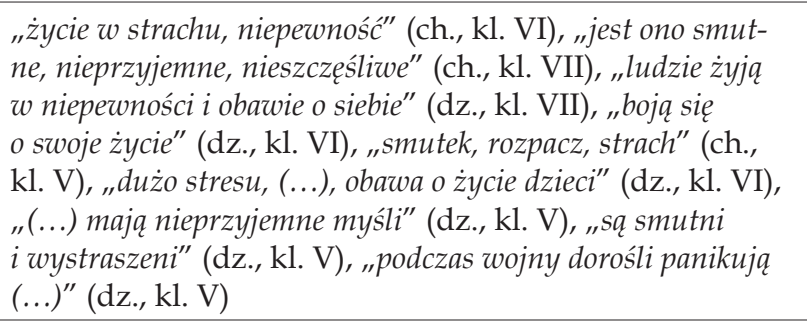 \\
\hline $\begin{array}{l}\text { Dążenie } \\
\text { do przeżycia }\end{array}$ & 10,95 & $\begin{array}{l}\text { "życie w trakcie wojny ludzi dorostych jest trudne (tak samo } \\
\text { jak dzieci). Staraja się przeżyć, chowają się" (dz., kl. VI), } \\
\text { "chronia się" (dz., kl. VII), "ukrywają się w bunkrze" (dz., } \\
\text { kl. V), "starsi ludzie próbują chronić siebie (...)" (dz., kl. V), } \\
\text { "najczęściej sa oni schowani w swoich bunkrach" (dz., kl. V), } \\
\text { "niektórzy walcza o własna skórę" (ch., kl. V), "próbuja nie } \\
\text { zginać (przeżyć)” (ch., kl. V) }\end{array}$ \\
\hline $\begin{array}{l}\text { Ochrona } \\
\text { innych ludzi }\end{array}$ & 7,85 & $\begin{array}{l}\text { "ludzie dorośli podczas wojny zazwyczaj staraja się uchronić } \\
\text { bliskich" (dz., kl. VI), "opiekuja się rodzina, buduja morale } \\
\text { i zaufanie, staraja się pomagać" (dz., kl. VII), "ludzie dorośli } \\
\text { w trakcie wojny muszą zrobić wszystko, aby uchronić swoja } \\
\text { rodzinę oraz ojczyznę" (dz., kl. VII), ",dorośli przede wszyst- } \\
\text { kim chca uchronić swoja rodzinę" (dz., kl. VII), "jeżeli sa } \\
\text { np. (...) lub opiekunami starszych osób (np. ich własnych } \\
\text { rodziców) z pewnościa chyba chca dla nich jak najlepiej, czę- } \\
\text { sto sami się poświęcaja”" (dz., kl. VII), "myśla, co zrobić ze } \\
\text { swoja rodzina, co zrobić, żeby wyszło jak najlepiej dla niej” } \\
\text { (ch., kl. VII) }\end{array}$ \\
\hline
\end{tabular}




\begin{tabular}{|c|c|c|}
\hline Utrata życia & 5,30 & $\begin{array}{l}\text { "w trakcie wojny ludzie (...) gina za ojczyznę" (ch. kl. VII), } \\
\text { "umieraja" (dz., kl. V), "(..) chca oddać życie za innych" } \\
\text { (ch., kl. IV), "gina" (ch., kl. V), "zaciagają się do wojska albo } \\
\text { sa do niego rekrutowani, dużo z nich nie wraca" (ch., kl. VI) }\end{array}$ \\
\hline Ucieczka & 5,11 & $\begin{array}{l}\text { "w trakcie wojny ludzie najczéściej uciekaja" (ch., kl. VII), } \\
\text { „życie dorostych w trakcie wojny (...) albo ucieczka" (ch., kl. } \\
\text { V), "musza uciekać i do tego opiekować się dziećmi" (dz., kl. } \\
\text { V), "uciekaja na emigrację" (ch., kl. V), "dorośli maja obowia- } \\
\text { zek walczyć, ale też mogą uciekać, więc walcza i uciekaja” } \\
\text { (dz., kl. V), "w trakcie wojny starsi ludzie wyjeżdżaja (...)" } \\
\text { (dz., kl. V) }\end{array}$ \\
\hline $\begin{array}{l}\text { Doświadcza- } \\
\text { nie przemocy }\end{array}$ & 0,91 & $\begin{array}{l}\text { "sa bici i zmuszani do niewolniczej pracy" (dz., kl. VII), } \\
\text { "przymusowa praca na wojnie, obozy koncentracyjne" } \\
\text { (dz., kl. VI) }\end{array}$ \\
\hline Inne & 0,72 & \\
\hline
\end{tabular}

Źródło: badania własne.

Z wypowiedzi części uczniów $(4,92 \%)^{27}$ wynika, że inne zadania w trakcie działań wojennych przypisane są mężczyznom a inne kobietom. Do zadań mężczyzn należy walka z przeciwnikiem i poświęcenie życia: "niektórzy dorośli mężczyźni wstępuja do wojska, a ci co nie wstępuja do wojska próbuja przeżyć" (ch., kl. VII), "jeśli chodzi o mężczyzn, to sa zabierani do walki" (dz., kl. VII), "mężczyźni najczęściej walczą" (dz., kl. V), "większość mężczyzn idzie na front" (ch., kl. VII), "mężczyźni: wstąienie do armii, udział w walkach" (dz., kl. VI). Zdaniem uczniów, mężczyźni muszą wykazać się męstwem i odwagą: "mężczyźni dzielnie walczą" (dz., kl. VI). Badani dostrzegają, że mężczyźni zostają odseparowani od rodziny: „dorośli, najczęściej mężczyźni, walcza na wojnach. Nie mogą wtedy być z rodziną" (dz., kl. V), co wiąże się z doświadczaniem "trudnych" emocji: „sa smutni i wystraszeni” (dz., kl. V).

Natomiast, do zadań kobiet należy:

- utrzymanie rodziny: „kobiety musza utrzymać rodziny, co jest utrudnione przez likwidowanie miejsc pracy" (ch., kl. VII), „kobiety gotuja”" (dz., kl. VII);

- troska o dzieci i innych członków rodziny: „kobiety w tym czasie zajmuja się dziećmi i resztą rodziny" (dz. kl. VII), "kobiety najczęściej chronia dzieci i próbują się ukryć" (dz., kl. V), "mama musi chronić dzieci” (dz., kl. V), "kobiety zajmuja się dziećmi i dobytkiem" (dz., kl. VII);

- walka o przeżycie swoje i dzieci: „kobiety zwykle walcza o życie swoje i ich dzieci" (dz., kl. V), „dziewczyny się chowają" (ch., kl. V);

${ }^{27}$ Nie zadałam pytania, które wymagałoby odniesienia się przez uczniów do zadań kobiet i mężczyzn w trakcie wojny. Spontaniczne odpowiedzi udzielone przez badanych pokazują tradycyjne, stereotypowe myślenie o zadaniach „męskich” i „kobiecych”. 
- wychowanie dzieci: „kobiety: ochranianie dzieci i wychowywanie ich jak najlepiej" (dz, kl. VI);

- praca w domu: „kobiety, jeżeli moga, pracują lub sa w domu” (ch., kl. VI), „kobiety pracuja w domu” (ch., kl. VII), "kobiety (...) pracuja, żeby mieć co jeść i pić" (dz., kl. V);

- działania pomocowe: „mężczyźni walcza, a kobiety im pomagaja” (ch., kl. VII);

- zadania sanitarno-medyczne: „kobiety opatruja rannych” (dz., kl. VII), "dorosłe kobiety najczęściej pracują w szpitalu" (dz., kl. VI), "kobiety opiekują się rannymi" (dz., kl. V), "kobiety ida np. do AK jako pielęgniarki wojskowe” (dz., kl. VI), "kobiety zostaja sanitariuszkami” (ch., kl. V).

Uczniowie dostrzegają, że w czasie wojennego niepokoju kobiety stają się obiektami przemocy: „kobiety są często wykorzystywane seksualnie przez ludzi wroga" (ch., kl. VII).

\section{Obraz aktywności dzieci w trakcie wojny według uczniów}

Na pytanie dotyczące aktywności dzieci w trakcie trwania wojny uczniowie sformułowali łącznie 668 propozycji. W swoich wypowiedziach przede wszystkim skoncentrowali się na własnych emocjach doświadczanych przez młode pokolenie uczestniczące w wojnie (prawie 34\% wypowiedzi). Dominowały głównie: lęk, strach oraz inne ujemne emocje, wyrażające niepokój o własne życie, życie najbliższych, niepewność, smutek, żal, przerażenie, rozpacz i tym podobne. Uczniowie wskazywali na „życie w stresie” i „emocjonalne rany" wywołujące cierpienie, prowadzące do „załamania nerwowego", z którego "trudno się wyleczyć". Próbowali też wyrazić słowami wyobrażenie o emocjach, które wywołane są poczuciem bezradności, bezsilności, różnego typu ograniczeniami, przymusem. Wiele wypowiedzi dotyczyło codziennego życia i aktywności wynikających z roli dziecka (zabawa, nauka), ale też takich, które, zdaniem badanych, młodzi ludzie podejmują tylko w sytuacji niewoli. Można do nich zaliczyć na przykład działalność konspiracyjną, w szczególności roznoszenie tajnych wiadomości, korespondencji i tym podobnych. Uczniowie wskazywali, że w trakcie wojny dzieci ukrywają się (prawie 12\% wypowiedzi). Część ich wypowiedzi wiąże się dokonywaniem ocen jakości życia młodego pokolenia w sytuacji wojennego niepokoju. Uczniowie oceniają życie dzieci w trakcie trwania wojny jako złe, smutne, straszne, okropne. Niewielka część odpowiedzi (0,61\%) została przyporządkowana do kategorii: „inne”, bowiem wypowiedzi kilkorga dzieci nie mieszczą się w żadnej z wyodrębnionych kategorii, co przedstawiono $\mathrm{w}$ tabeli 4. 
Aktywności dzieci podczas wojny w opiniach uczniów klas IV-VII

\begin{tabular}{|c|c|c|}
\hline $\begin{array}{l}\text { Kategorie } \\
\text { aktywności } \\
\text { dzieci }\end{array}$ & $\%$ & Przykładowe wypowiedzi uczniów \\
\hline Emocje & 33,98 & 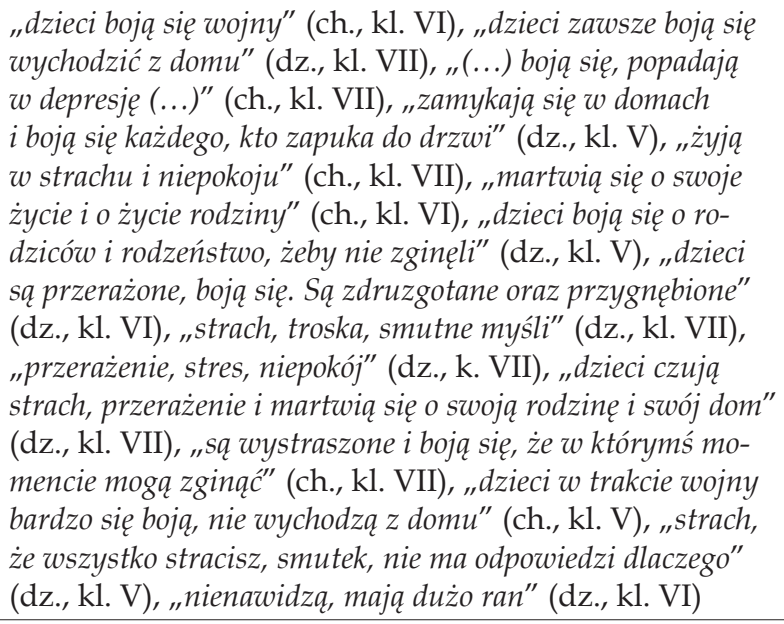 \\
\hline Codzienne życie & 19,31 & 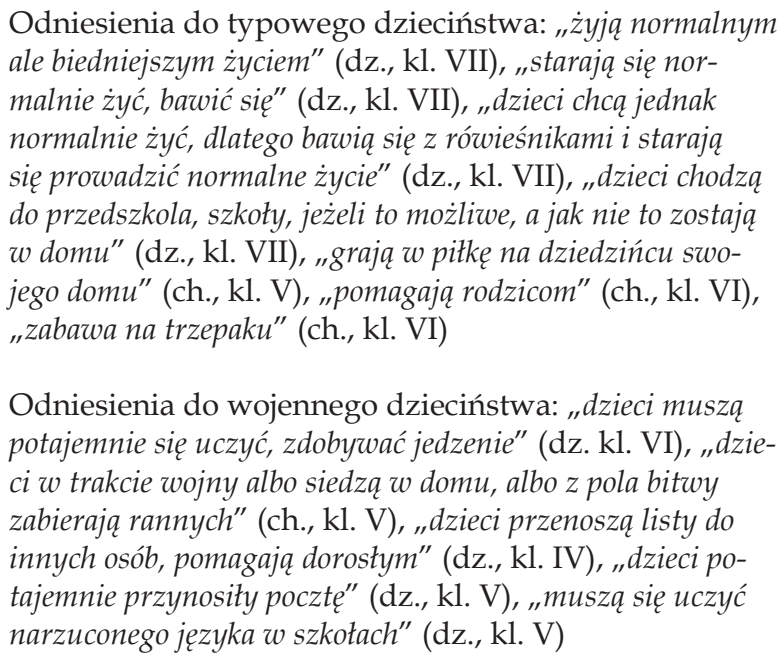 \\
\hline Ukrywanie się & 11,98 & 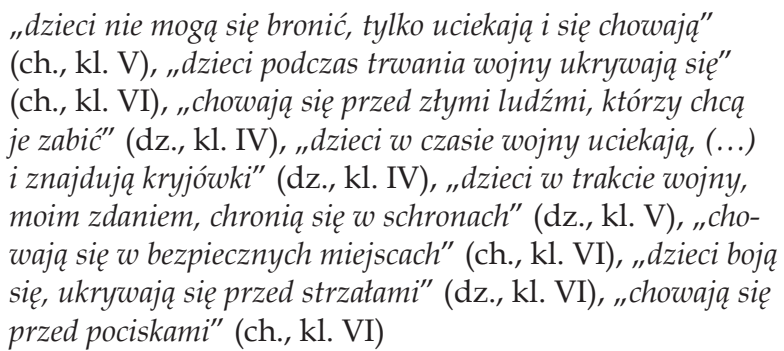 \\
\hline
\end{tabular}




\begin{tabular}{|c|c|c|}
\hline $\begin{array}{l}\text { Wojenne } \\
\text { dzieciństwo }\end{array}$ & 11,38 & $\begin{array}{l}\text { „myśle, że mają okropne dzieciństwo i pragna żyć w lep- } \\
\text { szych warunkach" (dz., kl. V), „wojna psuje im dzieciństwo } \\
\text { i wspomnienia oraz nie pozwala zbudować im ugrunto- } \\
\text { wanych wartości np. ufności" (dz., kl. VI), ",niefajnie, bo } \\
\text { muszą siedzieć w okopach i stuchać strzelanin" (ch., kl. VI), } \\
\text { "życie dzieci jest petne smutku i płaczu, jakby z jakiegoś } \\
\text { filmu dokumentalnego" (dz., kl. V), „życie dzieci w trakcie } \\
\text { trwania wojny wyglada okropnie (...)" (dz., kl. V), "dzieci } \\
\text { sa bardziej pokrzywdzone, niż dorośli, ponieważ dorośli spo- } \\
\text { ra czéśc swojego życia przeżyli a dzieci nie” (dz., kl. V), "źle } \\
\text { i niemiło (...)" (ch., kl. V) }\end{array}$ \\
\hline Walka & 5,83 & $\begin{array}{l}\text { "zostają wzięci do pobrania, tadowania i rzucania różnymi } \\
\text { broniami" (dz., kl. VI), "są szpiegami swojego kraju, ida na } \\
\text { wojnę" (ch., kl. V), "starają się walczyć o niepodległość" } \\
\text { (dz., kl. VII), "robia maty sabotaż, wstęuja do harcerstwa" } \\
\text { (ch., kl. VII), "niektóre odważne, a czasem nawet wszystkie } \\
\text { dzieci walcza z innymi” (dz., kl. V), "(...) potem przychodzi } \\
\text { duch walki i chca oddać krew za naszą ojczyznę" (ch. kl. } \\
\text { VII), "dzieci próbują walczyć poprzez strajki” (dz., kl. VII) }\end{array}$ \\
\hline Ucieczka & 5,69 & $\begin{array}{l}\text { "wyjeżdżaja z rodzicami do innego kraju" (dz., kl. V), "zo- } \\
\text { staja wywiezieni w bezpieczne miejsce" (ch., kl. V), "dzieci } \\
\text { uciekają z domów przed bombardowaniem" (dz., kl. V), } \\
\text { "caty czas przenoszone z miejsca na miejsce" (ch., kl. VI), } \\
\text { "dzieci w trakcie wojny stuchaja rodziców i wyjeżdżaja do } \\
\text { innych krajów" (dz., kl. V) }\end{array}$ \\
\hline $\begin{array}{l}\text { Utrata życia } \\
\text { własnego lub } \\
\text { bliskich }\end{array}$ & 4,49 & $\begin{array}{l}\text { "wojna to ciężki czas dla nich, bo często traca bliskich" } \\
\text { (dz., kl. VI), "większość umiera albo jest ranna" (dz., kl. V), } \\
\text { "sq w obozie koncentracyjnym, umierają tam" (dz., kl. V), } \\
\text { "umieraja np. w szpitalach" (ch., kl. VI), "wiele dzieci traci } \\
\text { swoich rodziców w czasie trwania wojny, a część traci własne } \\
\dot{z} y c i e^{\prime} \text { (ch., kl. VII) }\end{array}$ \\
\hline Ograniczenia & 4,34 & $\begin{array}{l}\text { "dzieci nie mogą się bawić" (dz., kl. V), "brak nauki, zaba- } \\
\text { wy" (ch., kl. V), "dzieciom brakuje miłości i radości” } \\
\text { (ch., kl. VI), "maja problem z nauka, szkoty raczej nie dzia- } \\
\text { tają" (ch., kl. VI), "nie mają możliwości realizowania swoich } \\
\text { marzeń, musza szybko dorosnać i nie moga się uczyć" } \\
\text { (dz., kl. VII) }\end{array}$ \\
\hline $\begin{array}{l}\text { Doświadczenie } \\
\text { przemocy }\end{array}$ & 2,39 & $\begin{array}{l}\text { "dzieci są bite, zła postawa dorostych w stosunku do dzieci" } \\
\text { (dz., kl. VI), "sq zabierane do obozów” (dz., kl. IV), "są cza- } \\
\text { sami brane w niewole ze swoimi rodzicami i ciężko pracuja" } \\
(\mathrm{dz.}, \mathrm{kl} . \mathrm{V}), \text {, są wykorzystywane do ciężkich prac" } \\
(\mathrm{dz.}, \mathrm{kl} . \mathrm{V})\end{array}$ \\
\hline
\end{tabular}

Źródło: badania własne. 
Uczniowie w swoich wypowiedziach wskazują, że doświadczenia wojenne dzieci są zróżnicowane ze względu na ich wiek: "mate dzieci nie zdają sobie wtedy sprawy co się dzieje” (dz., kl. VII), "dzieci w wieku 1-4 nie wiedza o co chodzi, w wieku 5-7 wiedza, że dzieje się coś złego, dzieci w wieku 11-16 lat już wiedza prawie wszystko. 17+ stają się przeciętnymi dorostymi" (dz., kl. VII). Uczniowie wskazują na niezrozumienie sytuacji, zagubienie młodszych dzieci w innej, niż wcześniej, rzeczywistości, na przykład: „zapewne (szczególnie młodsze) nie rozumieja, co się dzieje” (dz., kl. VII), "dzieci niektóre nie zdaja sobie sprawy, co to jest" (ch., kl. V), "sa nieświadome tego, co się dzieje” (dz. kl. V), ), "młodsze nie wiedza, co się dzieje, starsze rozumieja co się dzieje wokót nich" (ch., kl. V). Dostrzegają bezradność dzieci wobec sytuacji, w której się znalazły: „dzieci sa (...) zabłakane, bo nie wiedza, co się dzieje i nie wiedza, jak sobie z tym poradzić"' (dz., kl. VI).

\section{Podsumowanie}

Językowy obraz wojny w ujęciu uczniów klas IV-VII jest zróżnicowany i odzwierciedla zarówno indywidualną perspektywę, jak i perspektywę wspólną oraz perspektywę pokolenia, które nie doświadczyło wojny, a zna ją z przekazów historycznych, opracowań naukowych i dokumentów, filmów, literatury, przekazów popularyzatorskich i tym podobnych. Jest odzwierciedleniem tego, co uczniowie wiedzą na temat wojny z prezentowanych im faktów i ich interpretacji dokonywanych przez inne osoby. Stanowi zatem obraz „z drugiej ręki", wyobrażenie tego, czym jest, czym może być doświadczenie wojny.

Uczniowie w swoich wypowiedziach tworzą językowy obraz wojny jako złego, traumatycznego, "okropnego", stresującego doświadczenia ludzi. Wykorzystują znane im metafory i związki frazeologiczne lub tworzą własne, pozwalające nazwać, odzwierciedlić tragizm wojennych doświadczeń ludzi. Mówią o: „krwawej wojnie”, „krwawym piekle”, ,krwawym pobojowisku”, „ludzkiej rzeźni”, o doświadczeniu pozostawiającym „ślady, które trudno zmyć”, ,"katastrofie kraju i ludzi”, „rozwalonym świecie”, ,wielkiej masakrze", "katastrofalnych skutkach" i tym podobnych. Starają się zwerbalizować tragizm doświadczeń indywidualnych i zbiorowych, a właściwymi środkami językowymi stają się wulgaryzmy, jak "gówno", „wielkie gówno”. Zdaniem uczniów, ludzie podczas wojny uruchamiają różne strategie i sposoby bezpośredniej walki z przeciwnikiem (wrogiem, najeźdźcą, okupantem) i przemocy (walczą, biją się, zabijają, mordują, torturują, gazują, gwałcą, mszczą się, okaleczają, robią innym krzywdę itp.), ale również strategie przetrwania (ochrony siebie i innych ludzi, ucieczki przed niebezpieczeństwem). Dostrzegają różne doświadczenia ludzi ze względu na wiek i płeć. Jak wyni- 
ka z zaprezentowanego fragmentu badań, osoby dorosłe koncentrują swoją energię i działania wokół zabezpieczenia i organizacji codziennego życia własnego oraz bliskich, jak też ochrony dzieci przed zagrożeniem. Odmienne doświadczenia, zdaniem uczniów, mają jednak mężczyźni i kobiety. Pierwsi biorą udział w bezpośredniej walce, natomiast kobiety zajmują się organizowaniem życia i ochroną dzieci, ludzi starszych, innych członków rodziny. Inne doświadczenia są, według badanych, udziałem dzieci. Te, zdaniem uczniów, w sytuacji zagrożenia zdrowia i życia własnego oraz bliskich osób doświadczają „nieprzyjemnych” niechcianych emocji i uczuć „burzących harmonię i wyzwalających zachowania obronne" ${ }^{28}$, jak chowanie się, chronienie się, ucieczka. Z wypowiedzi badanych wyłania się trudny obraz rzeczywistości wojennej osób dorosłych oraz obraz bolesnego przepełnionego strachem, łzami dzieciństwa.

Na zakończenie warto podkreślić, że językowy obraz wojny wyrażony przez uczniów klas IV-VII jest nie tylko obrazem odpowiadającym ujęciu słownikowemu typu: wojna to walka, wojna to konflikt, wojna to starcie zbrojne; wartościującym: wojna to coś złego, wojna jest okropna, wojna jest zła, lecz zawiera wiele aspektów, niuansów, szczegółów niekoniecznie oczywistych, a istotnych z perspektywy badanych, gdyż podkreślanych w ich wypowiedziach, na przykład: „w trakcie wojny księża odprawiaja więcej mszy, a ludzie się modla”, "inni żyja jak nigdy nic, uciekaja od rzeczywistości, po prostu się tym nie przejmuja", "żotnierze walcza z rozkazów dowódców i nie mają możliwości się z nimi sprzeciwiać", "cywilni ludzie podczas wojny często sa po prostu bezbronni”, "dzieci boją się o swoich ojców", "chowają się przestraszeni w katach", "wojna zmienia życie o 180 stopni. Musza oni zrezygnować ze swojego dawnego życia”, ",bo ktoś może być mity, a tak naprawde w kieszeni trzyma broń". Powyższe refleksje i interpretacje sformułowane przez uczniów inspirują do kolejnych pytań, na przykład: Czego ludziom brakuje w trakcie wojny? Co można zrobić, żeby wojny uniknąć ${ }^{29}$, by uzupełnić opis językowego obrazu wojny z perspektywy uczniów klas IV-VII.

\section{BIBLIOGRAFIA}

Bartmiński J., Jezzykowe podstawy obrazu świata, Wydawnictwo UMCS, Lublin 2012.

Dereń E., Nowak T., Polański E., Słownik języka polskiego z frazeologizmami i przystowiami, ARTI, Warszawa 2012.

Drabik L., Kubiak-Sokół A., Sobol E., Wiśniakowa L., Słownik języka polskiego PWN, Wydawnictwo Naukowe PWN, Warszawa 2011.

${ }^{28}$ H. Gasiul, Teorie emocji i motywacji, Warszawa 2007, s. 35.

${ }^{29}$ Materiał znajduje się w opracowaniu i przygotowaniu do publikacji. 
Drabik L., Sobol E., Stankiewicz A., Stownik idiomów polskich PWN, Wydawnictwo Naukowe PWN, Warszawa 2006.

Gasiul H., Teorie emocji i motywacji, Wydawnictwo Uniwersytetu im. Kardynała Stefana Wyszyńskiego, Warszawa 2007.

https:/ / sjp.pwn.pl/szukaj/wojna.html, [dostęp: 15.04.2020 r.]

Hinczer F., Stosunek dziecka polskiego do wojny, „Szkoła Powszechna”, zeszyt II, Warszawa 1920.

Humboldt W., O myśli i mowie, Wydawnictwo Naukowe PWN, Warszawa 2002.

Kopaliński W., Stownik mitów i tradycji kultury, Oficyna Wydawnicza Rytm, Warszawa 2011.

Kuszak K., Interpretacje pojęcia wojny wedtug uczniów klas starszych szkoty podstawowej, [w:] Dziecięce interpretacje rzeczywistości. Werbalne i pozawerbalne reprezentacje dziecięcych znaczeń, red. E. Kochanowska, 2020 (w druku).

Nowak T., Język w świetle odkryć nauki, Petrus, Kraków 2011.

Popularny stownik języka polskiego, Wydawnictwo Ibis, Poznań 2009.

Stownik 3w1, wyrazów obcych, synonimów, frazeologiczny, Wydawnictwo Buchmann, Warszawa 2012.

Sobol E., Stownik frazeologiczny PWN z Bralczykiem, Wydawnictwo Naukowe PWN, Warszawa 2008.

Tokarski R., Światy za słowami. Wykłady z semantyki leksykalnej, Wydawnictwo UMCS, Lublin 2014. 